\title{
Granulosa cell tumor of the testis in a newborn
}

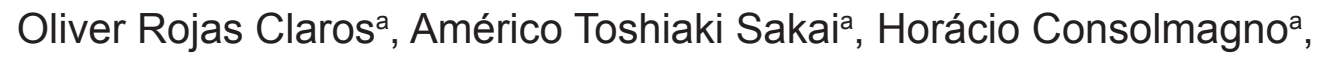

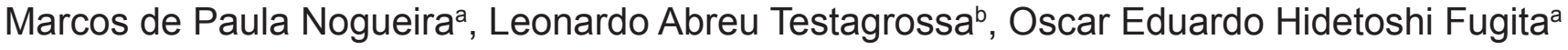

Claros OR, Sakai AT, Consolmagno H, Nogueira MP, Testagrossa LA, Fugita OEH. Granulosa cell tumor of the testis in a newborn. Autopsy Case Rep [Internet]. 2014; 4(1): 39-44. http://dx.doi.org/10.4322/acr.2014.006

\section{ABSTRACT}

Testicular neoplasms are uncommon tumors of childhood. These tumors comprise the germ cell tumors, and other tumors that may originate from histological testicular components, which are unrelated to the germinal lineage. Among the latter are the sex cord-stromal tumors (SCST), an important entity in newborns. SCSTs comprise, among others, granulosa cell tumors, which are more common in the ovary, but in rare cases may develop in the testis. The prognosis is excellent since it is universally benign. Diagnosis, which is sometimes challenging, is usually made after orchiectomy and pathological examination, which is characterized by morphological features and positive expression of inhibin, calretinin, and vimentin, and negative for alphafetoprotein. The authors present the case of a newborn with a right enlarged testis detected during the first examination after birth. Ultrasonography showed a heterogeneous solid/cystic mass in the right testis, without retroperitoneal lymphadenopathy. A right inguinal orchiectomy was performed 21 hours after birth. Pathologic examination revealed a juvenile granulosa cell tumor of the right testicle. After 4 years of follow-up, as expected, the child presented an uneventful outcome.

Keywords: Sex Cord-Gonadal Stromal Tumors; Granulosa Cell Tumor; Testicular Neoplasms; Infant, Newborn; Testis.

\section{CASE REPORT}

A 28-year-old mother gave birth to a male newborn at the 40th week of gestational age, through an uneventful vaginal delivery. The newborn weighted $3040 \mathrm{~g}$, and the Apgar score was 9, 10, 10. During the initial post-delivery examination, the neonatologist detected, as the sole alteration, an irregular, asymmetric, and enlarged right testis of a term newborn. This finding was confirmed by an ultrasonographic examination that showed a heterogeneous solid mass in the right testis without retroperitoneal lymph node involvement. Left testis was descended and external genitalia was normal Serum alpha-fetoprotein (AFP) and total human chorionic gonadotropin (hCG) determination was $97,819 \mathrm{ng} / \mathrm{mL}$ (within normal range for gestational age and birth weight) and $31,4 \mathrm{mUI} / \mathrm{mL}$ (reference value: $<5 \mathrm{mUI} / \mathrm{mL}$ ), respectively.

\footnotetext{
a Department of Surgery - Hospital Universitário - Universidade de São Paulo, São Paulo/SP - Brazil.

b Department of Pathology - Hospital das Clinicas - Faculdade de Medicina - Universidade de São Paulo, São Paulo/SP - Brazil.
}

Copyright $\odot 2014$ Autopsy and Case Reports - This is an Open Access article distributed of terms of the Creative Commons Attribution NonCommercial License (http://creativecommons.org/licenses/by-nc/3.0/) which permits unrestricted non-commercial use, distribution, and reproduction in any medium provided article is properly cited. 
A right inguinal orchiectomy was performed at 21 hours of age. Gross examination of the surgical specimen showed a light-brown colored, round, and solid mass measuring $3.0 \times 2.0 \times 1.5$ $\mathrm{cm}$. At the cut surface, a solid and firm sharply defined neoplasia replaced most of the testicle parenchyma, displacing the epididymis peripherally. The morphology was characterized by solid areas, and focal cystic structures resembling follicles containing a light basophilic watery substance (Figure 1A, 1C and 1D). These follicular-resembling areas showed multi-stratified clusters of neoplastic cells. The solid areas predominated and showed a lobulated arrangement formed by large cells with light eosinophilic cytoplasm, with rounded hyperchromatic nuclei and visible nucleoli, besides occasional nuclear infolding (Figure 1B). Mitotic and apoptotic cells were frequent. Immunostainings revealed diffuse positivity for vimentin and focal calretinin and inhibin, and negativity for $\beta$-hCG, alpha-fetoprotein and cytokeratins (Figure 2), thus ruling out yolk sac tumor, which was the major differential diagnosis.
The final diagnosis was juvenile granulosa cell tumor of the right testicle. The epididymis and rete testis were not involved but were displaced to the periphery. Neither necrosis nor infiltration of the tunica albuginea, nerves, or vessels was found. Surgical margins were free of neoplasia. The 4-year follow-up showed a healthy child without evidence of any testicular or scrotum complaints.

\section{DISCUSSION}

Testicular neoplasms are the most frequent tumor in young men, but are rare among children. Their incidence ranges between 0.5 and 2.0 cases per $1,000,000$ children. ${ }^{1}$ Approximately $10 \%$ of all testicular tumors are diagnosed during the neonatal period, ${ }^{2}$ comprising less than $1 \%$ of all childhood cancers. ${ }^{3}$ Testis tumors are represented by germ cell tumors, which are the leading histology, ${ }^{4}$ but any other histological testicular component may give rise to neoplasia. In this setting are the sex cord-stromal tumors (SCSTs), which account for approximately
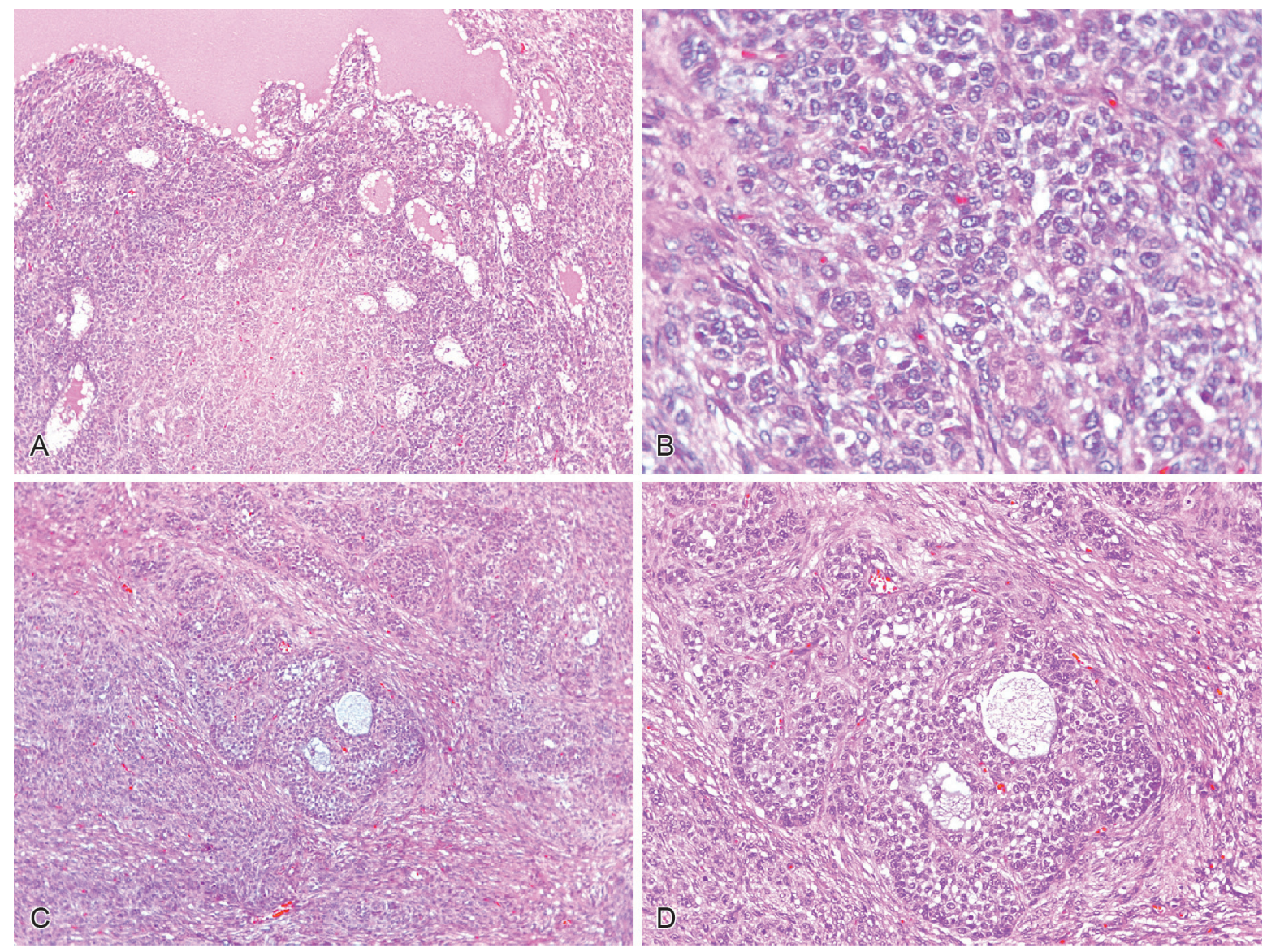

Figure 1 - Photomicrography of the testis tumor (H\&E). A - Panoramic view showing the neoplasia with cystic and solid areas, (100X); B - Details of the neoplastic cells, with rounded hyperchromatic nuclei and visible nucleoli, and occasional nuclear infoldings, (400X); C and D - Neoplastic cells arranged in follicularlike structures enclosing watery basophilic substance (C 200X, D 100X). 


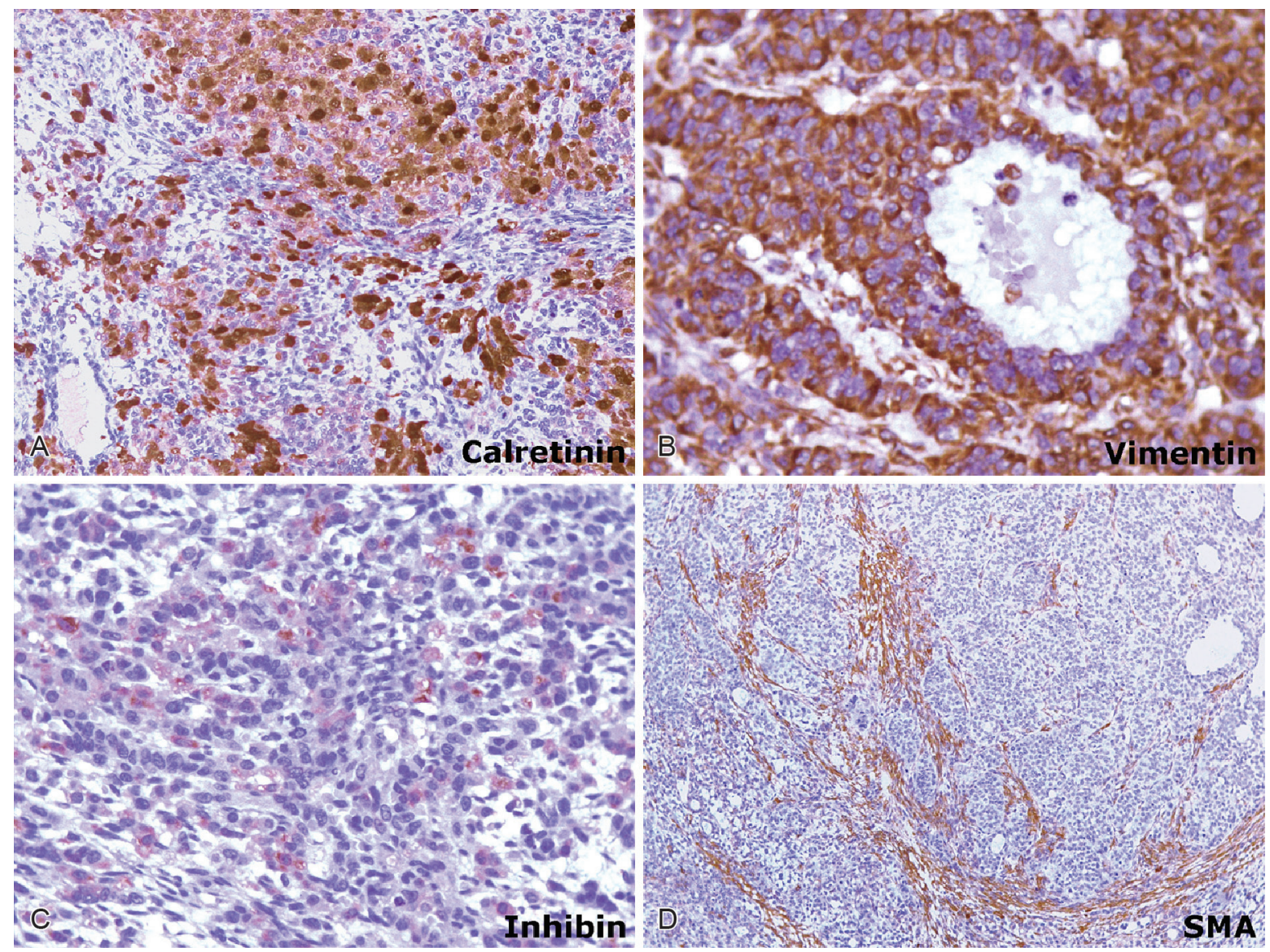

Figure 2 - Photomicrography of the testis tumor. Immunohistochemistry. A - Calretinin positivity in neoplastic cells (200X); B - Diffuse vimentin positivity in neoplastic cells (400X); C - Focal inhibin positivity (200X); D - Smooth muscle actin (SMA) positivity highlighting the lobular pattern of the tumor (100X).

$10-20 \%$ of all gonadal tumors during childhood, mostly during the neonatal period or infancy, indicating a prenatal origin of tumor development. 5,6

Granulosa cell tumor of the testis is a SCST distinguished in the adult and juvenile types. ${ }^{7}$ In 1983, Crump ${ }^{8}$ first described a case of a SCST in a 30-week-old fetus, but juvenile granulosa cell tumor (JGCT) was recognized as a distinct entity in 1985 due to its similarity to the ovarian granulosa cell tumor. ${ }^{9,10}$ The juvenile type accounts for $1.2 \%$ of all prepubertal testis tumors, representing the most common stromal sex cord neoplasm of the testis in infancy, and the most common neoplasm of the testis in the first 6 months of life. ${ }^{11-13}$ Until 2002, 48 cases had been described and compiled by Nieto et al, including a case report by the same author. ${ }^{14}$

JGCT is thought to arise from a specialized gonadal stromal cell of the testicle, which, histologically, is very similar to the JGCT of the ovary. This tumor usually affects the right and left testis equally, and the age at diagnosis ranges from neonates to 21 months. ${ }^{9,12,15,16}$ Clinical features are characterized by an asymptomatic testicular mass within the abdomen or inguinal region, or within the scrotal sac, and the lack of endocrinological features. Some cases present the contralateral testis as clinically normal but undescended. When associated to external genitalia abnormalities, like ambiguous genitalia or hypospadia, JGCT usually presents abnormal karyotypes involving $X / X Y$ mosaicism or structural abnormalities of the chromosome $Y^{12,17-19}$ Chromosomal abnormality linked to the $Y$ chromosome was reported to be found in $20 \%$ of the cases. ${ }^{18,19}$

AFP is a glycoprotein normally and equally produced by the yolk sac, liver, and gastrointestinal tract in early embryogenesis. ${ }^{20-22}$ Although the importance and usefulness of AFP as a tumor marker is well established, the reference value of AFP in newborns is still under standardization. Bader et al., ${ }^{22}$ studying 260 term and near-term newborns, found a reference interval for AFP concentrations at birth that was 15,700-146,500 ng/ $\mathrm{mL}$, based on $95 \%$ confidence interval. The median value was $48,300 \mathrm{ng} / \mathrm{mL}$, which constitutes a useful 
reference. ${ }^{23,24}$ Therefore, although elevated, the value of serum AFP of our patient was within normal limits for the gestational age and birth weight, which is in accordance with JGCT behavior and laboratory characteristics. As far as we know, and based on a thorough bibliographic research, elevation of hCG is not observed in JGCT of the testis. The mild elevation detected in our case was interpreted as a false-positive result, as observed in other testis tumors. ${ }^{25}$ Similarly, the method of dosage using Siemens kit accepts several interferences as causing false-positive results mainly in the range of 10-50 $\mathrm{mUI} / \mathrm{L}$. Therefore AFP and hCG determinations are considered useless tumor markers for this type of neoplasm. ${ }^{18,19}$ Imaging studies, mainly those obtained by ultrasound examination, show a complex cystic and solid mass.

Grossly, the tumor appears as a tan to yellow mass, within the parenchyma of the testis, with a mixture of solid and cystic regions without necrosis or hemorrhage. These cysts are thin-walled follicle structures that vary in size from $0.8 \mathrm{~cm}$ to $6.5 \mathrm{~cm}$, and contain viscid or gelatinous fluid or clotted blood. ${ }^{13,26,27}$ Microscopically, the cysts are lined with single or multiple layers of granulosa cells with or without solid nodules. In non-follicular areas, the cells grow in sheets, nodules, irregular clusters, and sometimes are dispersed loosely in the stroma. The nuclei are round to oval and hyperchromatic with visible nucleoli and varying amounts of eosinophilic cytoplasm. Mitoses may be prominent and often as numerous as 33 mitoses per 10 high power fields. 9,13,26 The high number of mitotic figures most likely represents the proliferative activity of the neonatal tissue, since JGCT are universally benign. ${ }^{28}$ The granulosa cells stain positive for cytokeratin and vimentin. ${ }^{26,29}$ As a gonadal stromal tumor, immunohistochemistry is also positive for CD99, inhibin, and calretinin. ${ }^{7,30}$ Characteristically, JGCTs do not stain for AFP.

Differential diagnosis includes yolk sac tumor, teratoma, cystic dysplasia of the testicle, Sertoli cell tumor, gonadoblastoma, and unclassified SCSTs. ${ }^{7,12,31}$ All the se tumors have been described as having cystic and solid components on ultrasound. In this context, morphologic features and adjunctive studies are capable of excluding most of the considered diagnostic possibilities. The presence of polyhedral cells with clear cytoplasm, microfollicules (Call-Exner bodies, which are multilayered folliclelike structures containing mucin), expression of inhibin, and lack of expression of AFP help to ascertain the diagnosis of JGCT in most cases. ${ }^{10}$
The prognosis is excellent because JGCT is a benign entity. The diagnosis is reached by pathological findings after orchiectomy, which remains the treatment of choice. However, in case of a pre-operatory high index of suspicion, and after definitive frozen sections diagnosis, it is possible to enucleate the tumor while sparing the remainder of testis. ${ }^{28}$

We report the case of a term newborn that presented a painless testicular mass diagnosed in the delivery room. The appropriate physical examination led to the early diagnosis, prompt treatment, and consequently, a favorable prognosis.

Pediatric testicular tumors are uncommon and usually present as painless testicular growths. Continuous and meticulous physical examination is the cornerstone to assure the early diagnosis and subsequent good prognosis in the childhood and perinatal period.

\section{REFERENCES}

1. Coppes MJ, Rackley R, Kay R. Primary testicular and paratesticular tumors of childhood. Med Pediatr Oncol. 1994;22:329-40. http://dx.doi.org/10.1002/mpo.2950220506

2. Walsh TJ, Grady RW, Porter MP, Lin DW, Weiss NS. Incidence of testicular germ cell cancers in U.S. children: SEER program experience 1973 to 2000. Urology. 2006;68:402-5. PMid:16904461. http://dx.doi.org/10.1016/j. urology.2006.02.045

3. Schneider DT, Terenziani M, Cecchetto G, et al. Gonadal and extragonadal germ cell tumors. In: Schneider DT, Brecht IB, Oslon TA, et al., editors. Sex cord stromal tumors and rare gonadal tumors. Heidelberg: Springer; 2012. p. 327402. PMid:22527330.

4. Harms D, Gottschalk I, Jänig U. Pathological anatomy of germ cell tumors (especially testicular tumors) in children. Klin Padiatr. 1983;195:181-9. PMid:6876681. http://dx.doi. org/10.1055/s-2008-1034066

5. Schneider DT, Jänig U, Calaminus G, Göbel U, Harms D. Ovarian sex cord-stromal tumors: a clinicopathologic study of 72 cases from the Kiel Pediatric Tumor Registry. Virchows Arch. 2003;443:549-60. PMid:12910419. http:// dx.doi.org/10.1007/s00428-003-0869-0

6. Hofman M, Schlegel PG, Hippert F, et al. Testicular sex cord stromal tumors: Analysis of patientsfrom Makei study. Pediatr Blood Cancer. 2013;60:1651-5. PMid:23733594. http://dx.doi.org/10.1002/pbc.24607 
7. Zugor V, Labanaris AP, Witt J, Seidler A, Weingärtner K, Schott GE. Congenital juvenile granulosa cell tumor of testis in Newborns. Anticancer research. 2010;30:1731-4. PMid:20592370.

8. Crump WD. Juvenile granulosa cell (sex cord-stromal) tumor of fetal testis. J Urol. 1983;129:1057-8. PMid:6854755.

9. Lawrence WD, Young RH and Scully RE: Juvenile granulosa cell tumor of the infantile testis. A report of 14 cases. Am J Surg Pathol. 1985;9:87-94. PMid:3976984. http://dx.doi. org/10.1097/00000478-198502000-00003

10. Shukla AR, Huff DS, Canning DA, et al. Juvenile granulosa cell tumor of the testis: contemporary clinical management and pathological diagnosis. J Urol. 2004;171:19002. PMid:15076304. http://dx.doi.org/10.1097/01. ju.0000120223.29924.3b

11. Ross JH, Rybicki L, Kay R. Clinical behavior and a contemporary management algorithm for prepubertal testis tumors: a summary of the Prepubertal Testis Tumor Registry. J Urol. 2002;168:1675-8. http://dx.doi.org/10.1016/S00225347(05)64386-8

12. Chan YF, Restall P, Kimble R. Juvenile granulosa cell tumor of the testis: report of two cases in newborns. J Pediatr Surg. 1997;32:752-3. http://dx.doi.org/10.1016/S00223468(97)90025-7

13. Young RH. Sex cord-stromal tumors of the ovary and testis: their similarities and differences with consideration of selected problems. Mod Pathol. 2005;18:S81-S98. PMid:15502809. http://dx.doi.org/10.1038/modpathol.3800311

14. Nieto N, Torres-Valdiviedo MJ, Aguado P, et al. Juvenile granulosa cell tumor of the testis: case report and review of literature. Tumori. 2002;88:72-4. PMid:12004856.

15. Thomas JC, Ross JH, Kay R. Stromal testis tumors in children: a report from the prepubertal testis tumor registry. J Urol. 2001;166:2338-40. http://dx.doi.org/10.1016/S00225347(05)65583-8

16. Uehling DT, Smith JE, Logan R, Hafez GR. Newborn granulosa cell tumor of the testis. J Urol. 1987;138:385-6. PMid:2439713.

17. Young RH, Lawrence WD, Scully RE. Juvenile granulosa cell tumor - another neoplasm associated with abnormal chromosomes and ambiguous genitalia. A report of three cases. Am J Surg Pathol. 1985;9:737-43. PMid:4061731. http://dx.doi.org/10.1097/00000478-198510000-00005

18. Raju U, Fine G, Warrier R, Kini R, Weiss L. Congenital testicular juvenile granulosa cell tumor in a neonate with $\mathrm{X} /$ XY mosaicism. Am J Surg Pathol. 1986;10:577-83. http:// dx.doi.org/10.1097/00000478-198608000-00008

19. Tanaka Y, Sasaki Y, Tachibana K, Suwa S, Terashima K, Nakatani $Y$. Testicular juvenile granulosa cell tumor in an infant with $X / X Y$ mosaicism clinically diagnosed as true hermaphroditism. Am J Surg Pathol. 1994;18:316-22. http:// dx.doi.org/10.1097/00000478-199403000-00013

20. Teilum G, Albrechtsen R, Norgaard-Pedersen B. The histogenetic-embryologic basis for reappearance of alphafetoprotein in endodermal sinus tumors (yolk sac tumors) and teratomas. Acta Pathol Microbiol Scand. 1975;83:80-6.

21. Brewer JA, Tank ES. Yolk sac tumors and alpha-fetoprotein in first year of life. Urology. 1993;42:79-80. http://dx.doi. org/10.1016/0090-4295(93)90347-D

22. Bader D, Riskin A, Vafsi O, et al. Alpha-fetoprotein in the early neonatal period - a large sutudy and review of the literature. Clin Chim Acta. 2004;349:15-23. PMid:15469851. http://dx.doi.org/10.1016/j.cccn.2004.06.020

23. Hyvarinen M, Zeltzer P, Oh W, Stiehm ER. Influence of gestational age on serum levels of alpha-1 fetoprotein, IgG globulin, and albumin in newborn infants. J Pediatr.1973;82:430-7. http://dx.doi.org/10.1016/S00223476(73)80116-7

24. Caballero C, Vekemans M, Lopez del Campo JG, Robyn C. Serum alpha-fetoprotein in adults, in women during pregnancy, in children at birth, and during the first week of life: a sex difference. Am J Obstet Gynecol.1977;127:384-9. PMid:65129.

25. Ballieux BEPB, Weijl NI, Gelderblom H, van Pelt J, Osanto $\mathrm{S}$. False-positive serum human chorionic gonadotropin (hCG) in a male patient with malignant germ cell tumor of the testis: a case report and review of literature. Oncologist. 2008,13:1149-54. PMid:18984875. http://dx.doi.org/10.1634/ theoncologist.2008-0159

26. Pinto MM. Juvenile granulosa cell tumor of the infant testis: case report with ultrastructural observations. Pediatr Pathol. 1985;4:277-89. http://dx.doi.org/10.3109/15513818509026901

27. Nistal M, Redondo E, Paniagua R. Juvenile granulosa cell tumor of the testis. Arch Pathol Lab Med. 1988;112:112932. PMid:3178427.

28. Fagin R, Berbescu E, Landis S, Strumpf K, Patil U. Juvenile granulosa cell tumor of the testis. Urology 2003;62:351. http://dx.doi.org/10.1016/S0090-4295(03)00355-8

29. Groisman GM, Dische MR, Fine EM, Unger PD. Juvenile granulosa cell tumor of the testis: a comparative immunohistochemical study with normal infantile gonads. Pediatr Pathol. 1993;13:389-400. http://dx.doi. org/10.3109/15513819309048227

30. Peterson C, Skoog S. Prenatal diagnosis of juvenile granulosa cell tumor of the testis. J Pediatr Urol. 2008;4:472-4 PMid:18760677. http://dx.doi.org/10.1016/j.jpurol.2008.04.005

31. Alexiev BA, Alaish SM, Sun CC. Testicular juvenile granulose cell tumor in a newborn: case report and review of the literature. Int J Sug Pathol. 2007;15:321-5. PMid:17652550. http://dx.doi.org/10.1177/1066896907302423 


\section{Conflict of interest: None}

Submitted on: $10^{\text {th }}$ January 2014

Accepted on: $16^{\text {th }}$ March 2014

Correspondence: Divisão de Clínica Cirúrgica

Hospital Universitário da Universidade de São Paulo

Av. Prof. Lineu Prestes, 2565 - Cidade Universitária - São Paulo/SP - Brazil

CEP: 05508-000 - Phone: +55 (11) 3091-9291; 3091-9489

E-mail: oscareh@hu.usp.br 